\title{
Giant Isolated Mesenteric Hydatid Cyst Case Report without Organ Involvement
}

\author{
Mezenteriyumdan Kaynaklanan Dev Kist Hidatik Olgusu: Diğer Organlari Etkilemeyen
}

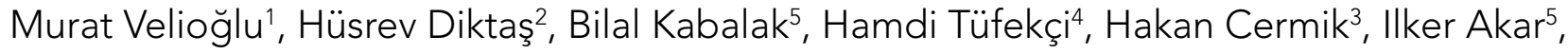 Bariş Yalçin' ${ }^{6}$ Alparslan Coşar}

'Department of Radiology, Girne Military Hospital, Girne, Cyprus

2Department of Infectious Diseases and Clinical Microbiology, Tatvan Military Hospital, Bitlis, Turkey

${ }^{3}$ Department of Pathology, Etimesgut Military Hospital, Ankara, Turkey

${ }^{4}$ Department of Anesthesiology and Reanimation, Girne Military Hospital, Girne, Cyprus

${ }^{5}$ Department of General Surgery, Girne Military Hospital, Girne, Cyprus

${ }^{6}$ Department of Microbiology, Girne Military Hospital, Girne, Cyprus

'Department of Biochemistry and Clinical Biochemistry, Girne Military Hospital, Girne, Cyprus

\section{ABSTRACT}

A 21 -year-old man presented with a 1-year history of intermittent attacks of abdominal distention and abdominal pain. Abdominal ultrasonography (USG) and abdominal computed tomography (CT) showed a large multicystic mass. After the operation, histopathological findings revealed a lamellated ectocyst and germinal layer with a thick outer, non-cellular membrane in the wall of the cyst, making a diagnosis of primary hydatid cyst for sure. He was discharged on the 10th postoperative day with albendazole $800 \mathrm{mg} /$ day treatment. Herein, we report an unusual case of an isolated primary hydatid cyst of the mesenterium. As a conclusion, in endemic areas, hydatid cysts should be considered for the diagnosis of a patient with cystic mass lesions. (Turkiye Parazitol Derg 2014; 38: 194-6)

Key Words: Mesenterium, hydatid cyst, multiloculated, abdominal

Received: 16.12 .2013

Accepted: 06.02.2014

\section{ÖZET}

21 yaşında erkek olgu yaklaşık bir yıldır devam eden abdominal şişkinlik ve karın ağrısı atakları şikayeti ile başvurdu. Abdominal ultrasonografi ve bilgisayarlı tomografide büyük multikistik kitle tespit edildi. Operasyon sonrasında histopatolojik bulgular neticesinde ince zar ile çevrelenmiş lamelli ektokist ve germinal tabaka tespit edildi. Kist duvarında non sellüler membrane primer kist hidatik tanısını doğruladı. Operasyon sonrası onuncu günde hasta 800 mg/gün albendazol tedavisi ile taburcu edildi. Burada nadiren gözlenen primer mezenteriyum kaynaklı hidatik kist olgusu sunulmuştur. Sonuç olarak, endemik bölgelerde kistik kitle saptanan olgularda kist hidatik mutlaka tanıda düşünülmelidir. (Turkiye Parazitol Derg 2014; 38: 194-6)

Anahtar Sözcükler: Mezenteriyum, hidatik kist, multilokule, abdominal

Kabul Tarihi: 06.02.2014

Address for Correspondence / Yazışma Adresi: Dr. Hüsrev Diktaş, Department of Infectious Diseases and Clinical Microbiology, Tatvan Military Hospital, Bitlis, Turkey. Phone: +90 5325725169 E-mail: hd3207@gmail.com DOI: $10.5152 /$ tpd.2014.3481

CCopyright 2014 Turkish Society for Parasitology - Available online at www.tparazitolderg.org

CTelif hakkı 2014 Türkiye Parazitoloji Derneği - Makale metnine www.tparazitolderg.org web sayfasından ulaşılabilir. 


\section{INTRODUCTION}

Hydatid disease is a parasitic infection caused by several species of the Echinococcus cestode. The most common form is E. granulosus, which produces cysts, primarily in the liver and lungs. E. multilocularis is much less common, producing an invasive tumor-like replacement of liver tissue. This disease is still endemic in many countries, such as Turkey, other parts of Eastern Europe, South America, Australia, and South Africa. Herein, we report an unusual case of an isolated primary hydatid cyst of the mesenterium.

\section{CASE REPORT}

A 21 -year-old man presented with a 1-year history of intermittent attacks of abdominal distention and abdominal pain. He had no operation history except an appendectomy 9 years ago. On the physical examination, his abdomen was diffusely tense without tender and rebound tenderness. Abdominal ultrasonography (USG) showed a large multicystic mass that was filling almost all abdominal quadrants and the pelvis. There were no mural nodules on the cyst walls or debris in it. Abdominal computed tomography $(C T)$ scan with contrast administration revealed a large, thin-walled $(<4 \mathrm{~mm})$ multiloculated cystic mass that extended from the left sub-diaphragmatic space to the retro-vesical space, which displaced the intestine to the right upper quadrant (Figure 1). The liver, spleen, pancreas, and both kidneys appeared normal. Hydatid serology was positive. The patient had a preoperative treatment with one monthly cycles of albendazole $800 \mathrm{mg} /$ day, in order to improve the surgical results and to reduce the risk of disease recurrence. The patient then underwent a complex operation. Laparotomy showed a giant cyst (multicystic nature) of the sigmoid colon mesentery that impaired the course of the associated colonic segment and was approximately $35 \mathrm{~cm}$ diameter (Figure 2). In the operation, the giant cyst was removed completely without breakage, and partial sigmoid resection was performed for healthy colonic passage. Histopathological findings revealed a lamellated ectocyst and germinal layer with a thick outer, non-cellular membrane in the wall of the cyst, making a diagnosis of primary hydatid cyst for sure. He was discharged on the $10^{\text {th }}$ postoperative day with albendazole $800 \mathrm{mg} /$ day treatment. The duration of treatment was 3 monthly, and his liver functions were controlled once a month. Abdominal (CT) scan with contrast administration was repeated at the sixth month after the operation and did not show any recurrence to date. Writen informed constent was obtained from patient who participated in this study.

\section{DISCUSSION}

Hydatid disease usually involves the liver and lungs. Uncomplicated cysts are usually asymptomatic. The symptoms are commonly related to complications and vary with regard to the location of the hydatid cysts. Symptomatic cysts have been reported occasionally in the spleen, kidney, peritoneal cavity, skin, and muscles (incidence of $2 \%$ each) and rarely in the heart, brain, vertebral column, ovaries, pancreas, gallbladder, thyroid gland, breast, and bones (1). Symptomatic cysts are usually larger than $5 \mathrm{~cm}$. Mild abdominal pain in the epigastrium, or right upper quadrant, hepatomegaly, or a palpable abdominal mass are quite common symptoms (2). In our case, the major symp-

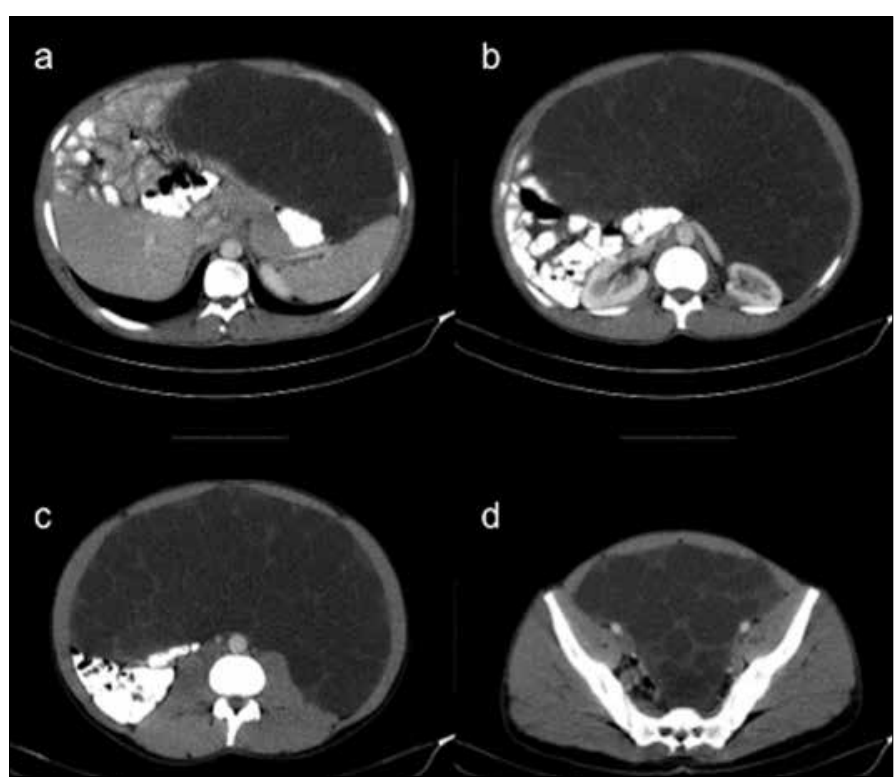

Figure 1. a-d. Axial CT images obtained through hepatic (a), renal (b), infrarenal (c) and pelvic level demonstrated multiloculated hipodens cystic mass with thin, non-enhancing walls extending from left upper-quadrant (a) to the retrovesical space (d).

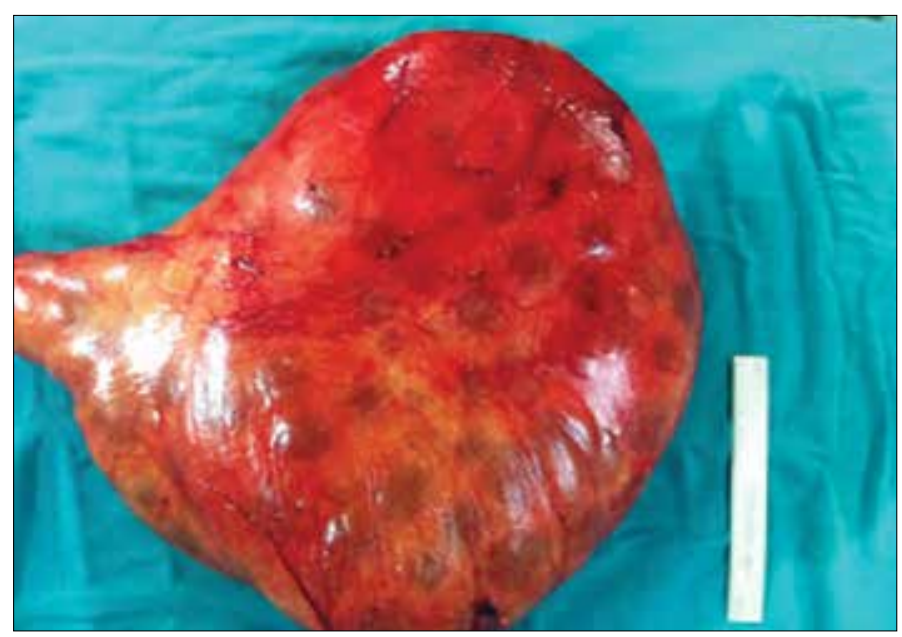

Figure 2. Intraabdominal multicystic mass after laparotomy.

toms were a giant abdominal mass that could be observed from outside of the abdominal wall and dyspepsia. In this situation, many of the diagnoses could be confused with hydatid cyst. The differential diagnosis is established by imaging and serological tests. Ultrasound, tomography, and magnetic resonance imaging have an almost $100 \%$ sensitivity and specificity. These techniques also help to differentiate hydatid cysts from other lesions, such as abscesses or tumors. Ultrasound and CT were used in our case with excellent diagnostic results (3).

Medical treatment with antihelmintic drugs, such as mebendazole and albendazole, has been introduced since 1977 as preoperative or postoperative chemotherapy. Many authors have reported that these agents can achieve clinical improvement of patients, increased life expectancy, and shrinkage of the cysts (4). Preoperative prophylaxis is very important to prevent intraoperative dissemination of cysts. We started prophylaxis with 
albendazole in the preoperative period, and this regimen may help to protect against dissemination and recurrence of disease. Also, continuing medical treatment for at least 3 months postoperatively is also suggested (5). In patients with symptomatic giant and multiorgan hydatid cysts, surgical removal of all cysts at the same time is recommended (6).

\section{CONCLUSION}

In endemic areas, hydatid cysts should be considered for the diagnosis of a patient with cystic mass lesions. The radiologic and immunological tests could assist physicians to make the differential diagnosis. Surgery still remains the mainstay in the management of hydatid disease, even in atypical locations, with medical treatment.

Informed Consent: Written informed consent was obtained from patient who participated in this case.

Peer-review: Externally peer-reviewed.

Author Contributions: Concept - M.V., H.D.; Design - B.K., H.T.; Supervision - A.C.; Funding - B.Y., A.C.; Materials - B.K., H.C.; Data Collection and/or Processing - H.D., M.V.; Analysis and/or Interpretation - B.K., M.V..; Literature Review - B.Y., H.D.; Writing - M.V., H.D.; Critical Review - B.K., H.C.; Other - I.A.

Conflict of Interest: No conflict of interest was declared by the authors.

Financial Disclosure: The authors declared that this study has received no financial support.
Hasta Onamı: Yazılı hasta onamı bu olguya katılan hastalardan alınmıştır.

Hakem değerlendirmesi: Dış bağımsız.

Yazar Katkıları: Fikir - M.V., H.D.; Tasarım - B.K., H.T.; Denetleme - A.C.; Kaynaklar - B.Y., A.C.; Malzemeler - B.K., H.C.; Veri Toplanması ve/veya İşlemesi - H.D., M.V.; Analiz ve/veya Yorum - B.K., M.V.; Literatür Taraması - B.Y., H.D.; Yazıyı Yazan - M.V., H.D.; Eleştirel İnceleme - B.K., H.C.; Diğer - I.A.

Çıkar Çatışması: Yazarlar çıkar çatışması bildirmemişlerdir.

Finansal Destek: Yazarlar bu çalışma için finansal destek almadıklarını beyan etmişlerdir.

\section{REFERENCES}

1. McManus DP, Zhang W, Li J, Bartley PB. Echinococcosis. Lancet 2003; 362: 1295-304. [CrossRef]

2. Silva MA, Mirza DF, Bramhall SR, Mayer AD, McMaster P, Buckels JA. Treatment of hydatid disease of the liver. Evaluation of a UK experience. Dig Surg 2004; 21: 227-33. [CrossRef]

3. Valle-Sanz Yd Yd, Lorente-Ramos RM. Sonographic and computed tomographic demonstration of hydatid cysts communicating with the biliary tree. J Clin Ultrasound 2004; 32: 144-8. [CrossRef]

4. Kaya Z, Gursel T. A pediatric case of disseminated cystic echinococcosis successfully treated with mebendazole. Jpn J Infect Dis 2004; 57: 7-9.

5. Dziri C, Haouet K, Fingerhut A, Zaouche A. Management of cystic echinococcosis complications and dissemination: where is the evidence? World J Surg 2009; 33: 1266-73. [CrossRef]

6. Sabouni F, Ferdosian F, Mamishi S, Nejat F, Monnajemzadeh M, Rezaei N. Multiple organ involvement with hydatid cysts. Iran J Parasitol 2010; 5: 65-70. 